\title{
A Study on the Economic Feasibility of 4-bed Rooms in Public Hospitals
}

\author{
공공병원의 4인병실 도입에 따른 경제적 타당성에 관한 연구 \\ Kwon, Soonjung* 권순정| Chai, Choul Gyun** 채철균 | Choi, Kwangseok*** 최광석
}

\begin{abstract}
Purpose: At the moment, a lot of Public Hospitals in Korea have adopted 5 or 6 bedrooms as a standard multi-bedroom type. However 5-6 bedrooms have many problems related to inpatient satisfaction and nosocomial diseases. Therefore 4 bedroom is under considering for standard multi-bed room in Public Hospitals in Korea. This paper tries to prove that adoption of 4 bedroom in Public Hospitals has nothing to do with economic loss which is now an obstacle in adopting 4 bedrooms. Methods: 3 Methods have been used in this paper. 1) Comparative analysis between medical insurance fee and service cost for hospitalization has been conducted through literature survey. 2) Scenario analysis has been used for the estimation of inpatient number when 4 bedrooms are adopted in Public Hospitals. 3) Relation analysis between profit and proportion of 4 bedroom in Public Hospitals. Results: Adoption of 4 bedroom as a standard multi-bedroom in Public Hospitals has been proved to have nothing to do with the economic loss of hospitals. Implications: It is necessary to introduce and expand 4 bedrooms instead of 5-6 bedrooms in hospitals for the upgrade of hospital environment and easy control of cross infection in inpatient bedrooms.
\end{abstract}

Keywords Public Hospital, Ward, 4-bed Room, Economic Feasibility

주 제 어 공공병원, 병동부, 4 인병실, 경제적 타당성

\section{Introduction}

\subsection{Background and Objective}

현재 국내 병원의 병동부 운영에 있어서 많은 병원이 기준 병실로 5인 이상의 병실을 선택하고 있으며, 공공병원도 예외 는 아니다. 병실의 정원을 5 인 이상으로 운영하는 것은 다음 과 같은 문제가 있어 향후 기준병실을 4 인 이하로 줄이는 것 에 대한 필요성이 대두되고 있다.1)

* Vice president, Professor, Ph.D. Department of Architecture, Ajou university (Primary author: sjkwon@ajou.ac.kr)

** Vice president, Professor, Dr.-Ing. Department of Architecture, Kwangwoon University (chai@kw.ac.kr)

*** Vice president, Ph.D. Executive Director, Heerim Architects and Planners (daumchois@hanmail.net)

이 논문은 2013년 보건복지부가 한국의료복지건축학회에 의뢰 한 "지역거점 공공병원 병동부 건축계획 기준 개발" 연구과제 의 최종보고서의 내용을 요약하여 작성하였음.

1) 2014년 현상설계를 통해 설계를 진행하고 있는 마곡 이화의료원 제2 부속병원의 경우 1000 병상을 모두 1 인실로 계획하고 있어 그 귀추가 주목된다.
인구 1000 명당 국내병원의 입원진료 병상수는 9.6 병상으 로 OECD 34개 국가 중 일본(13.4병상) 다음으로 병상이 많아 국내의 병상이 과잉공급되고 있음을 보여준다(보건복지부, 2013: 461). 이에 따라 향후 종합병원과 병원급 의료기관을 중심으로 과잉병실에 대한 구조조정이 예상되고 있다. 이 경 우 현행 기준병실의 규모는 5-6인실에서 4인실로 축소될 수 있다.

입원환자의 생활환경 측면에서 볼 때 5 6인병실의 경우 병실협소 및 영역성 미확보에 따른 환자 민원이 자주 제기되 고 있다. 특히 다인병실내에 환자, 보호자, 간병인 등 체류인 원이 과다하여 병실혼잡과 교차감염의 위험으로 병실내 안전 성, 쾌적성, 안정성 등을 유지하는데 어려움이 있다. 이에 따 라 입원환자에 대한 서비스개선차원에서 기준병실의 정원을 4인실로 줄이는 것에 대한 요구가 발생하고 있는 실정이다.

병원내 교차감염방지 측면에서 입원실에 많은 환자가 혼잡 하게 섞여 있는 것보다는 환자수가 적은 것이 유리하다. 특히 최근 들어 세계적으로 발생하고 있는 중동호흡기증후군 (MERS), 조류인플루엔자(H7N9, H5N1, H5N8), SARS, 신종인 
플루엔자 등이 출현하면서 원내 감염에 대한 주의가 더욱 필 요해지고 있어 병실내 정원을 과다하게 유지하는 것은 감염 문제의 발생 소지가 많다. 더욱이 간병인의 병실 도우미배치 가 법적으로 제도화되면 병실이 더욱 혼잡해질 우려가 있으 므로 병실 환경의 쾌적성 및 교차감염방지의 측면에서 기준 병실의 병상수를 줄이는 것이 필요하다.

공공병원의 경우 2011년 입원환자수가 2006년에 견주어 $3 \sim 5 \%$ 증가에 머무르고 있다. 국민 입원진료비 총액증가에 비하면 지역거점 공공병원의 이러한 현상은 기능 위축을 의 미하며, 이를 회복하기 위해서는 국민의료 요구변화에 적극적 으로 대응할 필요가 있다. 이러한 점을 감안할 때 해당 공공병 원들은 현 5 인 이상의 기준병실 운영형식에서 4 인병실을 기 준병실로 적정 병실규모를 전환하는 것에 대한 고려가 필요 하다.

2014년 9월부터 4인실 및 5인실도 건강보험이 적용되어 환자의 부담이 경감될 전망이다(경향신문, 2014).2) 다만 현재 의 6 인병실(기준병실)을 $50 \%$ 이상 확보하게 되어 있어 급격히 4인실이 일반화되지는 않을 전망이다. 아래 표에서 종합병원 을 기준을 할 때 4 인병실( 51,200 원) 및 5 인병실 $(52,000)$ 의 병 실료 합계가 6 인병실의 병실료 합계(48,000원)보다 더 많기 때문에, 그리고 4 5인병실의 면적과 6 인병실의 면적이 유사 하기 때문에 종합병원의 입장에서는 6 인실보다는 4 5인실의 설치를 선호할 가능성이 높아졌다.

[Table 1] Bedroom Fee after Reform of Medical Insurance Fee (2014.09)

\begin{tabular}{c|c|c|c|c|c|c}
\hline \multirow{2}{*}{ 구분 } & \multicolumn{2}{|c|}{ 4인실(원) } & \multicolumn{2}{c|}{ 5인실(원) } & \multicolumn{2}{c}{ 6인실(원) } \\
\cline { 2 - 7 } & 현행 & 개편후 & 현행 & 개편후 & 현행 & 개편후 \\
\hline 상급종합 & 67,770 & 24,150 & 41,770 & 13,080 & 9,770 & 10,060 \\
\hline 종합병원 & 42,770 & 12,800 & 33,770 & 10,400 & 7,770 & 8,000 \\
\hline 병원 & 29,680 & 9,270 & 25,680 & 7,530 & 5,680 & 5,790 \\
\hline 출전) 경향신문, 2014.07.08. \\
http://news.khan.co.kr/kh_news/khan_art_view.html?artid=20 \\
1407082119495\&code=940601
\end{tabular}

본 연구에서는 이러한 점을 감안하여 국내 공공병원의 기 준병실을 4 인병실로 축소하는 방안에 대하여 검토하고자 한 다. 지금까지 4 인 병실에 대한 환자와 근무자의 선호도 및 만 족도 조사 등에 대한 환경적 연구는 일부 진행되었지만 기준 병실을 4 인실로 운용하는 것에 대한 경제적 타당성이 충분히 밝혀지지 않은 점을 감안하여 본 연구에서는 4 인병실의 경제 적 타당성을 밝히는 것을 주요 목적으로 한다.

2) 이에 따라 상급종합병원의 경우 일반병상 비율이 평균 $65 \%$ 에서 $74 \%$ 로 증가하고, 그 아래 병원급의 일반 병상 비율은 평균 $74 \%$ 에서 $83 \%$ 까지 늘어나게 된다. 더 나아가 내년에는 모든 상급종합병원이 최소 $70 \%$ 이상의 일반병상을 의무적으로 확보하도록 한다는 것이 보건복지부의 방침이다. 참고로 보건복지부는 현재 기준 병실의 의 무 비율을 전체 병상의 50\%로 규정하고 있다(2014년 3월 기준)

\subsection{Methods of Research}

우선적으로 국내 공공병원의 범위, 경영상태, 시설현황 등 을 파악하여 공공병원의 문제점 및 개선방향을 파악하였다. 이러한 사항은 특히 병동부를 중심으로 수행되었다.

공공병원의 기준병실을 5-6인실에서 4인실로 전환하는 것에 따른 경제성 분석은 아래와 같이 3 가지 측면에서 검토되었다.

1) 문헌검토

기존에 연구된 입원료 원가 및 수가에 대하여 검토하였다. 입원료 원가가 보험에서 책정된 수가보다 낮은 경우 입원환 자수 증가가 병원의 수익증가로 연결되지 않을 수 있음을 파 악하고자 하였다.

\section{2) 시나리오 분석}

기준병실을 5-6인실에서 4인실로 전환하는 경우 전체 입원 환자수가 줄어드는 대신 병상이용율이 증가할 수 있음을 가 정하여 실제적으로 입원환자수의 감소가 크지 않음을 분석하 였다. 이때 신포괄수가제의 적용에 따라 입원환자 평균 재원 일수가 줄어드는 경우를 감안하였다.

3) 4 인실의 설치비율과 의료수지와의 상관성분석

공공병원의 병상규모와 의료수익의 상관성, 4 인실의 설치 비율과 의료수익의 상관성 등을 분석하였다. 이를 통해 입원 환자를 많이 받는 것이 통계적으로 병원의 수익에 도움이 되 지 않는 점과, 4 인실의 도입이 병원의 수익성에 연관성이 없 음을 증명하고자 하였다.

위의 세 가지 분석을 통해 본 연구에서는 공공병원의 기준 병실을 5-6인실에서 4인실로 전환할 경우 병원의 수익성을 악화시키지 않는다는 점을 설명하고자 하였다.

\section{Present Condition of Public Hospitals}

\subsection{Range of Public Hospitals}

공공병원은 크게 지방의료원과 적십자병원으로 구분된다. 공공병원의 대부분인 32개소(82.1\%)가 지방자치단체가 설립 한 지방의료원으로서 광역자치단체인 시도의 관할 아래에 있 으나, 목포시의료원과 울진군의료원 2 개소(5.1\%)는 기초자치 단체인 시군구가 설립하여 운영, 관리하고 있다. 지방의료원 외에 대한적십자사에 소속된 적십자병원이 5 개소(12.8\%)로, 이 병원들의 경우는 지방자치단체와 관련 없이 대한적십자사 의 관리체계 안에서 운영된다.

의료기관 종별로는 종합병원급이 32개소(82.1\%)로 공공병 원의 대부분을 차지하고 있으며, 7 개소(17.9\%)가 병원급이다. 종합병원 중 지방의료원이 29 개소, 적십자병원이 3 개소이고, 병원 중에는 지방의료원이 5 개소, 적십자병원이 2 개소를 차 지하고 있다(삼일회계법인, 2012:33).

공공병원이 소재한 지역은 대도시 6개소(15.4\%), 중소도시 28 개소(71.6\%), 군지역 5개소(13.0\%)로 대다수가 중소도시에 
위치하고 있다. 공공병원 가운데 지방의료원은 대도시에 4 개 소(11.8\%), 중소도시에 26개소(76.4\%), 군지역에 4개소 $(11.8 \%)$ 가 위치해 있다. 적십자병원은 대도시에 2개소 (40.0\%), 중소도시에 2 개소(40.0\%), 군지역에 1 개소(20.0\%)가 위치하고 있다(삼일회계법인, 2012:33).

2013년 03월 기준으로 공공의료원은 포괄적 2차 진료를 수행하는 중소규모의 의료기관으로 종합병원 29 개, 병원 5 개 로 구성되어 있다. 지방의료원의 평균병상수는 262 병상이다 (공공의료과, 2013).

지방의료원은 기관별 평균 연간 12 억 내외의 지원(국가 : 지자체 $=50: 50)$ 을 받고 있어 향후 효과적인 사업비집행 계 획수립 및 실행이 필요한 상황이다. 적십자병원의 경우에는 병원평균 연간 9 억원이 모두 국비로 지원되고 있어 공공병원 은 경제적으로 자립이 어려운 특성을 갖는다(공공의료과, 2010).

\subsection{Economic Index of Public Hospital in 2012}

1) 의료수지

2009년 기준 지역거점 공공병원 대부분(85\%)이 적자를 기 록하였다. 평균적으로 1 기관당 연간 13 억원의 적자가 발생하 였다. 더욱이 누적적자가 심화되고 있으며, 2009년말 병원당 누적적자가 147억에 이르고 있다(공공의료과, 2010).

수익구조 측면에서 볼 때, 민간병원의 당기순이익 규모가 백병상당 2.8 억임에 비해서 공공병원은 3.0 억의 적자가 발생 하여 공공병원의 수익구조가 민간병원에 비해서 매우 낮은 수준임을 알 수 있다. 다만, 공공병원의 경우 의료수익 증가율 측면에서 2009년도 $11.8 \%, 2010$ 년도 8.2\% 2011년 7.2\%로서 양호한 수준을 유지하고 있으며, 이 증가율은 민간병원의 평 균치(각각 $11.6 \%, 5.1 \%, 5.5 \%)$ 보다 높다. 이에 따라 향후 공공 병원과 민간병원의 수익률 격차가 다소 줄어들 것으로 예상 된다. 현재 공공병원의 100 병상당 진료수익은 민간병원 대비 78\%에 달하고 있다(한국보건산업진흥원, 2012).

[Table 2] Medical Treatment Income of Public and Private Hospitals (2010)

\begin{tabular}{c|c|c|c}
\hline 구분 & $\begin{array}{c}\text { 지역거점 } \\
\text { 공공병원 }\end{array}$ & 민간병원 & 비고 \\
\hline $\begin{array}{c}\text { 환자 1인당 } \\
\text { 외래진료비 }\end{array}$ & 35천원 & 45천원 & $\begin{array}{c}\text { 민간병원 } \\
\text { 대비 78\% }\end{array}$ \\
\hline $\begin{array}{c}100 \text { 병상당 } \\
\text { 진료수익 }\end{array}$ & 59억원 & 80억원 & $\begin{array}{c}\text { 민간병원 } \\
\text { 대비 74\% }\end{array}$ \\
\hline
\end{tabular}

공공병원의 의료수지가 악화된 이유로는 수익대비 인건비 비율 과다(민간병원의 1.5 배), 환자당 평균 진료비 과소 등이 주요한 원인으로 지목된다. 의료인력 가운데 인건비가 비교적 낮은 공중보건의사의 비중(28.9\%)이 높은데도 불구하고 병원
전체의 인건비 비율이 높은 것은 문제의 소지가 있다. 특히 의 사인력에 있어서도 공공병원은 100 병상당 전문의가 9.6 명으 로 동규모 민간병원의 12.1 보다도 적은 실정이다(삼일회계법 인, 2012:49). 이러한 점을 감안하면 공공병원은 의사직 이외 에서 인건비 지출이 높다고 볼 수 있다.

공공병원의 환자당 병원비는 민간병원의 $65-88 \%$ 에 불과하 다. 이러한 주요 원인은 공공병원의 의료급여비율이 높기 때 문이다. 전체 의료비중 의료급여비율은 공공의료원이 $28 \%$, 민간병원이 $17 \%$ 를 차지하고 있다(공공의료과, 2010).

\section{2) 의료수지비율}

공공병원의 의료수지비율은 2011년 $81.7 \%$ 에서 2012년 $80.8 \%$ 로 감소하였다. 2012년 경상수지비율은 92.3\%로 2011 년과 유사하다. 공공병원중 흑자병원이 9 개소에 불과하다. 공 공병원의 경우 인건비 비율의 증가로 의료수지가 악화되었고 의료외 수익의 증가로 이를 벌충한 것으로 분석된다(삼일회 계법인, 2012:173).

3) 의료수익 대비 인건비 비율

2012년 의료수익 대비 인건비 비율은 $68.9 \%$ 로 2011년 (67.4\%)에 비해 증가하여 인건비 부담이 늘어났으나, 2012년 전문의 1인당 의료수익이 798백만원으로 2011년(747백만원) 대비 증가하여 전문의 1 인당 수익성은 개선되었다(삼일회계 법인, 2012:171).

4) 병상이용율 및 재원일수

공공병원의 병상이용율은 2011년 $83.7 \%$ 에서 2012년 $84.4 \%$ 로 소폭 높아졌다. 이 가운데 병상이용율 $90 \%$ 이상인 병원이 11 개소(28.2\%)로 가장 많다. $75 \%$ 미만인 병원은 7 개소 이다.

평균재원일수는 2011년 12.8일에서 2012년 12.6일로 줄어 들었다. 평균재원일수 11 일 이하인 병원이 14 개소, 17 일을 초 과하는 병원이 3개소로 나타났다(삼일회계법인, 2012:167). 일반적으로 병상이용율이 높고 재원일수가 적은 것이 병원경 영에 유리한 것으로 알려져 있다.

5) 입원환자 증가

2011년 입원환자수가 2006년에 비해 3 5\%만 증가하였다. 그동안 고령화와 더불어 우리나라 국민의 입원진료비 총액이 엄청나게 늘어난 것에 비하면 지역거점 공공병원의 입원환자 가 늘지 않은 것은 상대적으로 공공병원의 기능 위축을 의미 한다고 볼 수 있다(삼일회계법인, 2012:56).

\subsection{Present Condition of Facility}

1) 시설의 노후 및 면적의 협소

2012년 기준으로 건축경과년수 30년 이상 병원이 7 개소 (18\%), 21-30년 경과한 병원이 10 개소(26\%)가 있다(삼일회계 법인, 2012:38). 지역거점 공공병원의 상당수가 70-80년도에 
건축되어 노후화가 심각한 수준이므로 시설의 보강이 필요하 며, 이때 병실환경을 개선하는 것이 포함되어져야 한다.

2011 년 기준으로 공공의료원의 시설면적은 $10,000 \mathrm{~m}^{2}$ 미만 $25.6 \%, 10,000 \sim 20,000 \mathrm{~m}^{2} \quad 46.2 \%, 20,000 \sim 30,000 \mathrm{~m}^{2} \quad 17.9 \%$, $30,000 \mathrm{~m}^{2}$ 이상 $10.3 \%$ 로 평균이 $17,544 \mathrm{~m}^{2}$ 의 규모를 갖는다. 공 공병원의 운영병상당 평균 시설면적은 $69.6 \mathrm{~m}^{2}(21$ 평)로 나타났 다. 지방의료원은 병상당 평균면적이 $70.7 \mathrm{~m}^{2}(21.4$ 평), 적십자 병원은 운영병상당 평균면적이 $62.1 \mathrm{~m}^{2}(18.8$ 평)로 적십자병원 이 지방의료원에 비해 병상당 시설면적이 다소 낮게 나타났 다(삼일회계법인, 2012:41).3)

\section{2) 병실 및 병상 현황}

공공병원들은 기준병실을 1 인실에서 15 인실까지 운영하고 있으며, 상급병실은 1 인실에서 5 인실까지의 범위를 보이고 있다. 29개 공공병원이 5 인실을 기준병실로 운영하고 있어, 5 인병실이 가장 많은 기준병실로 사용되고 있음을 알 수 있다. 이때 5인병실의 병실수는 평균 21개(병상수평균은 105 병상) 로 나타났다. 1 인실을 상급병실로 운영하는 병원이 36 개소로 가장 많으며 병상수(병실) 평균은 14 병상이다.

지방의료원의 경우 기준병실을 5 인실로 운영하는 병원이 27 개소로 가장 많으며 병실수 평균은 22개, 병상수 평균은 110 병상이다. 15 인실 규모의 큰 병실을 기준병실로 운영하 는 병원도 1 개소가 있다. 1 인실을 상급병실로 운영하는 병 원이 33 개소로 가장 많으며 병원당 1 인실 수 평균은 15 실 이다.

적십자병원의 경우 기준병실을 6 인실로 운영하는 병원이 3 개소로 가장 많으며 병실수 평균은 19 개, 병상수 평균은 112 병상이다. 적십자병원은 모두 2인실을 상급병실로 운영하며 병실수 평균은 8 개, 병상수 평균은 16 병상이다(삼일회계법인, 2012:42).

한국보건산업진흥원이 2013년 2월 실시한 전국 의료기관 입원환경 현황분석 결과를 살펴보면 시설, 설비 수준 평가결 과 의료기관별 차이가 상당한 것으로 드러났다. 상급종합병원 의 기준병상 비율은 $65 \%$, 종합병원의 경우 $72 \%$ 그리고 병원 은 $81 \%$ 를 기록하고 있다. 기준병상 비율은 병원규모와 반비 례하여, 병원의 규모가 클수록 기준병상의 비율이 낮은 것을 보여준다. 다만, 규모가 적은 의원급 의료시설은 기준병상의 비율이 오히려 병원급 의료시설보다 다소 높게 나타나 시설 의 고급화가 일부 도입된 것으로 판단된다.

3) 참고로 2009년 기준 공공병원의 병상당 연면적은 $56.4 \mathrm{~m}^{2}$, 상급종 합병원 및 특수병원을 제외한 전체 병원(민간+공공)의 병상당 연 면적은 $63.8 \mathrm{~m}^{2}$ 로 공공병원의 병상당 연면적이 민간병원에 비해 적음을 알 수 있다(보건복지부 외, 2011:25). 건축연면적은 출처 별로 면적에 차이가 발생하는 점을 감안할 필요가 있다. 면적산 정방법 및 기준의 차이, 답변의 오류 등이 그 원인이 될 수 있다.
[Table 3] Non Insurance Beds by Hospital Type

\begin{tabular}{|c|c|c|c|c|c|c|}
\hline \multirow[b]{2}{*}{ 요양종별 } & \multirow[b]{2}{*}{ 기관수 } & \multirow{2}{*}{$\begin{array}{l}\text { 상급병상 } \\
\text { 운영기관수 }\end{array}$} & \multirow{2}{*}{$\begin{array}{c}\text { 상급병상 } \\
\text { 운영기관 } \\
\text { 비율 }\end{array}$} & \multicolumn{2}{|c|}{ 입원실 } & \multirow{2}{*}{$\begin{array}{l}\text { 일반 } \\
\text { 병상 } \\
\text { 비율 }\end{array}$} \\
\hline & & & & $\begin{array}{l}\text { 상급 } \\
\text { 병상 }\end{array}$ & $\begin{array}{l}\text { 일반 } \\
\text { 병상 }\end{array}$ & \\
\hline $\begin{array}{c}\text { 상급 } \\
\text { 종합병원 } \\
\end{array}$ & 43 & 43 & $100 \%$ & 12,914 & 24,412 & $65 \%$ \\
\hline 종합병원 & 278 & 276 & $99 \%$ & 24,481 & 62,121 & $72 \%$ \\
\hline 병원 & 1,430 & 1,140 & $80 \%$ & 27,359 & 119,523 & $81 \%$ \\
\hline 요양병원 & 1,121 & 475 & $42 \%$ & 10,204 & 150,595 & $94 \%$ \\
\hline 의원 & 28,058 & 4,022 & $14 \%$ & 21,375 & 66,882 & $76 \%$ \\
\hline
\end{tabular}

출전) 한국보건산업진흥원, 의료기관 입원환경 현황분석 보고서, 2013.3

2012년 지역거점 공공병원 운영평가 보고서(삼일회계법인, 2012)에서 공공병원이 운영하고 있는 상급병실 운영현황을 살펴보면 1 인실을 상급병실로 운영하고 있는 공공병원의 비 율이 $92.3 \%, 2$ 인실 상급병실 운영비율은 $76.9 \%$ 로 나타나, 1 인실의 상급병실 채택비율이 가장 높은 것을 보여준다. 공공 병원의 기준병실 분포현상을 살펴보면 5 인실을 기준병실로 사용하고 있는 공공병원의 비율이 $74.4 \%, 6$ 인실은 $69.2 \%, 4$ 인실은 $46.2 \%, 3$ 인실은 $23.1 \%$ 로 나타나, 5 인 병실을 기준병 실로 채택하는 비율이 가장 높은 것을 보여준다. 한편, 공공병 원에 따라서는 1 2인실을 기준병실으로 운영하는 경우도 10 개소로 나타났다.

3) 시설관련 당면과제

공공병원에 대한 국고지원 현대화사업으로 여러 의료원들 이 신축, 증축 등 대규모 시설투자를 하면서 2011년 기준 건 축경과연수가 21년 이상인 기관(1991년 이전 건축)이 2010년 에 비해 25 개소에서 17 개소(43.5\%)로 축소되었다. 그러나 여 전히 일부 의료원들은 낙후된 이미지를 벗지 못하고 있어 해 당 의료원들에 대하여 전반적인 시설 현대화를 위한 투자가 필요한 실정이다.

시설수준 향상을 위해서는 일부 의료원들의 시설면적 확대 및 병실규모의 적정화가 필요하다. 지역거점 공공병원의 운영 병상당 시설면적평균이 69.6m²로(삼일회계법인, 2012:41).2009 년 $\left(56.4 \mathrm{~m}^{2}\right)$ 에 비해 다소 개선되었지만(보건복지부 외, 2011:25) 여전히 좁아 필수 기능공간 및 환자 휴게-편의시설 등의 확보가 어려운 문제가 발생하고 있다.

병실 규모는 5 인 이하로 운영함이 권장되나, 일부 기관에서 6 인 이상의 병실을 운영하여 개인별 사적(私的) 공간이 확보 되지 않는 등 입원 시설의 수준이 낮은 문제점이 나타나고 있 다. 이에 따라 해당 의료원들은 적정병실규모(5인병실 이하 권장)로 시설전환이 필요하다(삼일회계법인, 2012:45). 
[Table 4] Insurance and Non Insurance Beds in Public Hospitals (2011. 12. 31)

\begin{tabular}{|c|c|c|c|c|c|c|c|}
\hline \multirow{2}{*}{\multicolumn{2}{|c|}{ 구분 }} & \multicolumn{3}{|c|}{ 기준병실 } & \multicolumn{3}{|c|}{ 상급병실 } \\
\hline & & \multirow{2}{*}{$\begin{array}{c}\begin{array}{c}\text { 기관 } \\
\text { 수 }\end{array} \\
4\end{array}$} & \multirow{2}{*}{\begin{tabular}{|c|}
$\begin{array}{c}\text { 기관당 } \\
\text { 평균 } \\
\text { 병실수 }\end{array}$ \\
4 \\
\end{tabular}} & \multirow{2}{*}{$\begin{array}{c}\text { 기관당 } \\
\text { 평균 } \\
\text { 병상수 } \\
4\end{array}$} & \multirow{2}{*}{$\begin{array}{c}\begin{array}{c}\text { 기관 } \\
\text { 수 }\end{array} \\
36\end{array}$} & \multirow{2}{*}{$\begin{array}{c}\begin{array}{c}\text { 기관당 } \\
\text { 평균 } \\
\text { 병실수 }\end{array} \\
14\end{array}$} & \multirow{2}{*}{$\begin{array}{c}\begin{array}{c}\text { 기관당 } \\
\text { 평균 } \\
\text { 병상수 }\end{array} \\
14\end{array}$} \\
\hline \multirow{12}{*}{ 전체 } & 1인실 & & & & & & \\
\hline & 2인실 & 6 & 6 & 11 & 30 & 7 & 14 \\
\hline & 3인실 & 9 & 2 & 6 & 9 & 3 & 10 \\
\hline & 4인실 & 18 & 6 & 22 & 9 & 5 & 19 \\
\hline & 5인실 & 29 & 21 & 105 & 2 & 7 & 35 \\
\hline & 6인실 & 27 & 15 & 90 & & & \\
\hline & 7인실 & 8 & 6 & 43 & & & \\
\hline & 8인실 & 11 & 3 & 22 & & & \\
\hline & 9인실 & 4 & 2 & 14 & & & \\
\hline & 10인실 & 6 & 2 & 18 & & & \\
\hline & 11인실 & 2 & 1 & 11 & & & \\
\hline & 15인실 & 1 & 1 & 15 & & & \\
\hline \multirow{12}{*}{$\begin{array}{c}\text { 지방 } \\
\text { 의료원 }\end{array}$} & 1인실 & 3 & 4 & 4 & 33 & 14 & 15 \\
\hline & 2인실 & 5 & 5 & 10 & 25 & 7 & 14 \\
\hline & 3인실 & 8 & 2 & 5 & 8 & 3 & 9 \\
\hline & 4인실 & 17 & 6 & 24 & 8 & 5 & 19 \\
\hline & 5인실 & 27 & 22 & 110 & 1 & 10 & 50 \\
\hline & 6인실 & 24 & 15 & 87 & & & \\
\hline & 7인실 & 6 & 7 & 49 & & & \\
\hline & 8인실 & 10 & 3 & 23 & & & \\
\hline & 9인실 & 4 & 2 & 14 & & & \\
\hline & 10인실 & 5 & 2 & 20 & & & \\
\hline & 11인실 & 1 & 1 & 11 & & & \\
\hline & 15인실 & 1 & 1 & 15 & & & \\
\hline \multirow{12}{*}{$\begin{array}{c}\text { 적십자 } \\
\text { 병원 }\end{array}$} & 1인실 & 1 & 1 & 1 & 3 & 8 & 8 \\
\hline & 2인실 & 1 & 7 & 14 & 5 & 8 & 16 \\
\hline & 3인실 & 1 & 5 & 15 & 1 & 4 & 12 \\
\hline & 4인실 & 1 & 1 & 4 & 1 & 4 & 16 \\
\hline & 5인실 & 2 & 8 & 38 & 1 & 4 & 20 \\
\hline & 6인실 & 3 & 19 & 112 & & & \\
\hline & 7인실 & 2 & 3.5 & 25 & & & \\
\hline & 8인실 & 1 & 1 & 8 & & & \\
\hline & 9인실 & 0 & 0 & 0 & & & \\
\hline & 10인실 & 1 & 1 & 10 & & & \\
\hline & 11인실 & 1 & 1 & 11 & & & \\
\hline & 15인실 & 0 & 0 & 0 & & & \\
\hline
\end{tabular}

출전) 삼일회계법인, 2012, 2012 지역거점 공공병원 운영평가 결과 보고서, p.42

\subsection{Propriety of Inpatient Care}

입원건당진료비(ECI, Episode Costliness Index) 조사 결과, 지역거점 공공병원이 민간의 비교병원군에 비해 입원진료비
가 4 10\% 비쌌고4) 병원 종별, 건강보험 자격과 상관없이 입 원진료 전반에서 진료비수준이 비교병원보다 상대적으로 다 소 높게 나타났다(삼일회계법인, 2012:66).

입원건당 재원일수(ELI, Episode Lengthiness Index) 조사 결과, 종합병원급 지역거점 공공병원이 비교병원보다 재원일 수가 6 26\% 길었고 병원급만 분석하였을 때에는 비교병원보 다 재원일수가 $8 \%$ 짧게 나타났다.

지역거점 공공병원의 경우 입원진료 패턴을 볼 때 경증 환 자를 진료하면서도 진료비가 높고 재원일수가 긴 그룹이 있 는 것으로 나타났다.5) 경증환자가 오래 병원에 입원하는 경우 병원의 주 수입원이 입원료가 되기 때문에 적정 입원수가가 담보되지 않으면 병원의 경영에 불리한 점이 있다. 일반적으 로 경증환자가 오래 입원하는 행태는 의료기관의 입장에서나, 건강보험관리자의 입장에서나 바람직하지 않기 때문에 미국, 영국은 물론 한국에서도 병원의 평균 재원일수를 줄이려는 노력이 시도되고 있다.

2011년부터 지역거점 공공병원에 신포괄수가제 적용이 시 작되었다. 이에 따라 각 병원이 입원진료비와 재원일수를 적 정한 범위로 유지하기 위해 더욱 노력해야 할 것이다. 재원일 수를 통제할 경우 입원병상의 가동율이 오히려 낮아질 가능 성이 있어 이를 감안한다면 기준병실을 4 인실로 축소 조정하 는 것이 더욱 바람직한 대안으로 볼 수 있다.

\section{Profit and Loss Analysis for 4-bedrooms}

\subsection{Profit Analysis of Inpatient Care through Literature Survey}

1) 한국보건사회연구원의 건강보험급여 원가보전율

한국보건사회연구원에서 조사한 의료기관 부문별 건강보 험급여 원가보전률을 살펴보면 건강보험급여수가가 의료원 가의 $90 \%$ 수준으로 조사되고 있다. 그리고 입원료 부문을 포 함하고 있는 기본진료료(진찰료+입원료+간호관리료)는 (종 합)병원급 의료기관의 경우 의료원가의 $54.2 \%$ 수준에 머물고 있는 것으로 나타났다. 이것은 입원비의 원가보전율이 낮다는 개연성을 보여준다. 특히, 대규모 병원일수록 기본진료료의

4) 301 병상이상 지역거점 공공병원의 전체 입원환자 ECI 평균이 $1.097( \pm 0.127)$ 이고, 300 병상이하 지역거점공공병원의 전체입원 환자 ECI 평균은1.044( \pm 0.094$)$ 이며, 병원급 $\mathrm{ECI}$ 평균은 1.051 $( \pm 0.071)$ 임. ECI평균이 1 보다 큰 값이 산출되어 지역거점 공공병 원이 비교병원보다 진료비수준이 높음. 참고로 $\mathrm{ECI}$ 가 1 인 경우 해당병원의 진료비 수준이 비교병원과 같음을 의미함. 다만 본 지표에서는 비급여가 포함되지 않아 해석에 유의해야 함(삼일회 계법인, 2012:102).

5) 건강보험환자 진료에서 총 12 개소의 의료기관(301병상 이상 종 합병원: 2 개소, 300 병상 이하 종합병원: 8 개소, 병원: 2 개소), 의료 급여환자 진료에서는 총 15 개소(301병상 이상 종합병원: 3 개소, 300 병상 이하 종합병원: 10 개소, 병원: 2 개소)의 의료기관이 이러 한 패턴을 보임. 
원가보전율이 낮아 대형병원의 경우 수술, 처치, 검사료 등을 통해 원가보전율을 일부 만회한다고 볼 수 있다.

[Table 5] Medical Insurance Repayment Rate for Medical Treatment (\%)

\begin{tabular}{c|c|c|c|c|c}
\hline \multirow{2}{*}{ 구 분 } & \multirow{2}{*}{ 합 계 } & \multicolumn{4}{|c}{ 유 형 } \\
\cline { 3 - 6 } & & 수술료 & 처치료 & $\begin{array}{c}\text { 기능 } \\
\text { 검사료 }\end{array}$ & $\begin{array}{c}\text { 기본 } \\
\text { 진료료 }\end{array}$ \\
\hline 상급병원 & 82.0 & 71.7 & 71.6 & 55.5 & 50.7 \\
\hline (종합)병원 & 86.4 & 91.3 & 82.8 & 97.1 & 54.2 \\
\hline 의 원 & 95.3 & 62.6 & 92.4 & 74.3 & 108.7 \\
\hline 평 균 & 89.6 & 75.2 & 86.1 & 75.0 & 89.9 \\
\hline
\end{tabular}

출전) 신영석 외, 2011, 유형별 상대가치 개선을 위한 의료기관 회 계조사, 한국보건사회연구원

2) 평가

위 연구에서는 실제의 병실 입원료가 원가에 미치지 못하 고 있는 것을 보여준다. 그렇다면 기준병실을 5 6인실로 하 여 병상을 채우는 것보다 4 인실을 운영하면서 수술, 처치, 검 사 등의 급성기 의료서비스를 제공하거나 의료 서비스의 질 을 높이는 것이 병원의 수익면에서 오히려 유리할 수 있다.

\subsection{Scenario Analysis}

1) 시나리오

기존의 5 인 이상 병실을 4 인실로 전환하는 경우 전체적인 병상수 감소 및 이에 따른 부수적인 변화가 수반되므로 4인실 전환에 따른 경제성 분석은 이러한 조건들을 설정하여 수행 되는 것이 바람직하다.

우선적으로 기준병실을 4인실로 전환하게 되면 전체 병원 병상수의 감소가 발생하며, 병상이용률은 올라갈 수 있다. 병 상이용률이 상승하는 이유는 의료수요는 단기간에 변하지 않 는 반면 병상공급이 줄어들었기 때문이며, 이와 동시에 병실 환경 개선에 따른 입원환자수의 유인이 발생할 수 있기 때문 이다. 2012년 기준 공공병원의 평균 병상이용률이 $84.4 \%$ 이므 로 4 인 병실 도입에 따른 병상이용률을 $90 \%$ 로 가정한다.

참고로 건강보험공단 일산병원의 경우 4 인실이 기준병실 이고 2012년 말 기준으로 4인실의 병상이용률은 $92 \%$, 전체 병상이용률은 $89 \%$ 이다. 입원환자의 평균재원일수는 8.3 일을 기록한 바 있다. 신포괄수가제의 적용으로 재원일수를 통제할 경우 공공병원의 실제 병상이용률은 더 낮아질 수 있다.

\section{2) 가동 병상수}

기준병실 5 인실을 4 인실로 변경하는 경우, 평균적으로 한 개 병원에서 운영되고 있는 5인실 105 병상6)이 84 병상으로

6) 기준병실을 5 인실로 운영하는 29 개 공공의료원에 대한 5 인실의 평균 병상수임(표4 참조).
축소되어 병상수 감소분은 21 병상으로 예상된다. 공공의료원 의 평균병상수를 236병상7)으로 하고 병상이용률을 $84.4 \%$ 로 하는 경우 평균 가동병상수는 약 199병상이다.

5인실을 4인실로 하는 경우 평균 병상수는 약 215병상으 로 축소된다. 앞서 제시된 바와 같이 4 인실을 기준병상으로 사용하는 공공병원의 병상이용률을 $90 \%$ 로 높인다고 가정하 면 공공병원의 평균가동병상수는 약 194 병상이 된다. 기준병 실이 5 인실인 경우보다 약 5 병상정도가 감소한다. 여기에 평 균재원일수를 줄이는 것까지 감안하면 실제적으로 5 인실을 4인실로 변경해도 입원환자수 변화는 크지 않을 것으로 예상 된다.

현재 공공병원은 입원환자수가 잘 늘지 않고 있다. 빈 공실 을 유지하는 것 보다는 병상이용률을 높이는 것이 바람직하다.

\section{3) 평가}

전체적으로 공공병원의 병상이용률(84.4\%)이 높기 때문에 경우에 따라서는 기준병실을 4 인실로 변경하는 것이 재무적 측면에서 불리할 수 있다. 따라서 병상이용률이 낮은 공공병 원을 선별하여 시범적으로 병동개선사업을 진행하는 것이 바 람직하다. 그러나 재원일수가 길기 때문에 재원일수를 줄인다 면 4인실로 운영하는 것이 경영측면에서 유리할 수 있다. 실 제적으로 공공병원들의 경우 꼭 입원하지 않아도 되는 환자 가 계속 입원하는 경향이 있어 이를 줄이고 보다 집중적으로 입원환자 진료를 하면 경영환경이 더 개선될 여지가 있다.

\subsection{Relation Analysis between the Number of Hospital Beds and Hospital Profit}

1) 일반병상수와 의료수지의 상관성

2010년도 34개 공공의료원에 대한 연보내용을 토대로 공 공의료원의 일반병상수(독립변수) 및 4 인병상 비율(독립변수) 과 의료수지(종속변수)와의 상관성을 분석하였다.

공공의료원의 일반병상수 규모와 의료수지의 상관분석 결 과 공공의료원의 병상수가 많을수록 의료수지 적자폭이 큰 것 으로 나타났다(상관도=0.50). 아래 그래프에서 알 수 있듯이 결정계수(0.2458)는 작지만 시각적으로 비례관계가 보이고, 회귀분석에서 유의한 $\mathrm{F}$ 값(P값)이 매우 작아 $(\mathrm{P}=0.00286<0.01)$ 충분한 설명력이 있다고 판단된다. 이러한 결과는 공공병원의 병상수를 많이 확보하는 것이 의료수지 개선에 도움이 되지 않는 것을 보여준다.

7) 2010 년 공공병원의 평균 병상수임. 


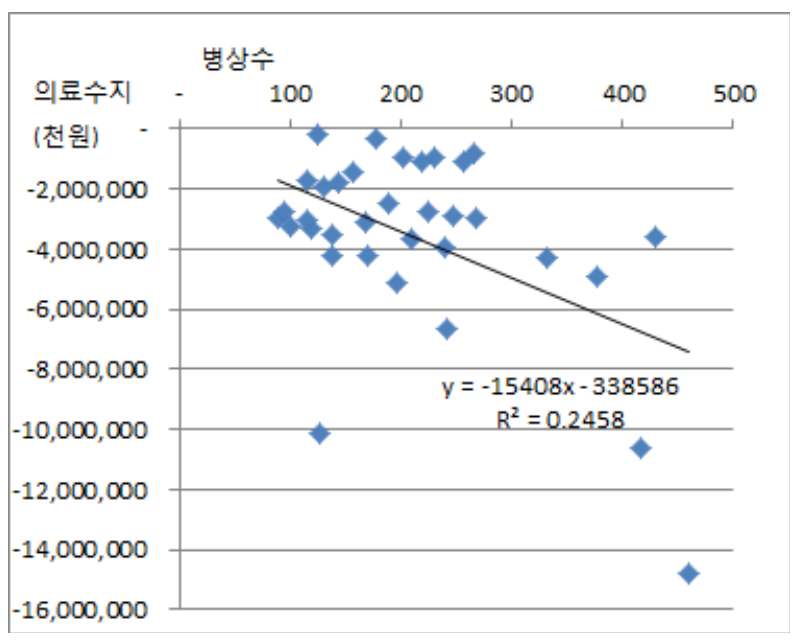

[Figure 1] Relationship between the number of hospital beds and amount of loss in Public Hospitals

2) 4 인병실 비율과 의료수지의 상관성

공공의료원의 4 인병상 비율과 의료수지의 상관성(상관도 $=0.08, \mathrm{P}=0.6443>0.05)$ 은 없는 것으로 나타났다. 여기서 4 인 병상 비율은 의료원의 일반병상수(정신, 격리, 행려, 진폐 등 특수병상수 제외)에 대한 4 인병상 비율을 의미한다. 따라서 공공의료원의 경우 4 인 병상을 일정부분 설치하는 것이 의료 원의 경영수지에 부정적인 영향을 미친다고 보기 어렵다.

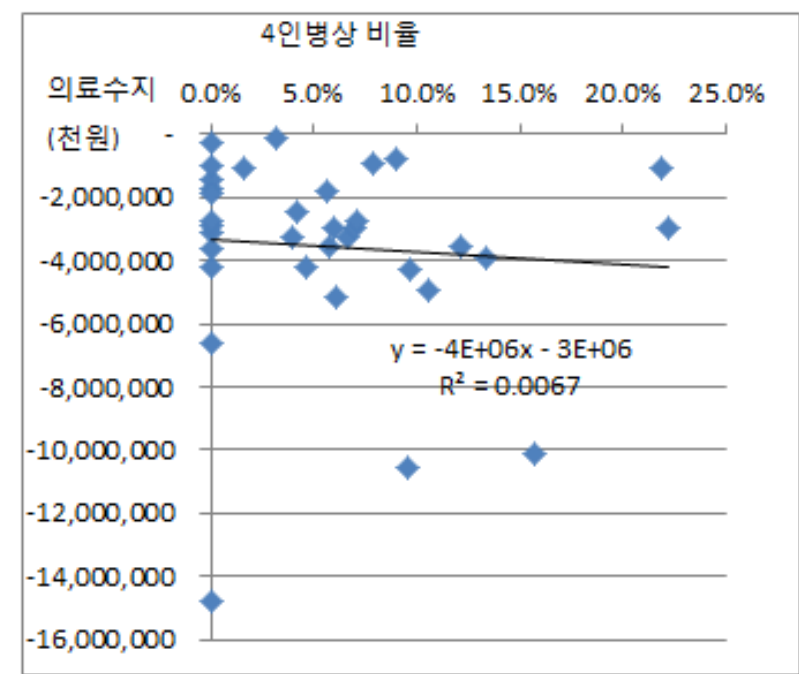

[Figure 2] Relationship between the proportion of 4-bedrooms and amount of loss in Public Hospitals

3) 평가

이러한 검토결과를 볼 때 현행 수가체계에서는 공공병원의 병실부문에서 수지균형을 맞추기는 어려운 실정이다. 병상을 많이 운영할수록 병원의 적자폭이 증가할 수 있는 구조적인 요인이 있어 병상수를 늘리는 것이 경제적이라고 보기 어렵 다. 따라서 현재 공공병원의 일반적 기준병실인 5 인실 또는 6 인실을 4 인실로 변경하더라도 경영적인 측면에서 불리하다
고 보기 어려우며 오히려 긍정적인 요소가 증가할 수 있을 것 이다. 물론 이것은 4 인실이 기준병실로 규정되기 이전의 분석 이며 향후 기준병실에 대한 병실료 수가체계가 변경될 경우 분석결과도 달라질 수 있을 것이다.

\section{Conclusions}

미국, 독일 등의 의료시설에서 병실의 정원은 대부분 2 인 이하이고, 4 인실 이하가 기준인 일본의 경우에도 최근 병실당 평균 병상수가 더 줄어들고 있는 추세이다. 이러한 배경은 생 활환경의 개선에 따른 환자의 병실환경에 대한 질적 요구 증 대, 병원내 교차감염의 억제 필요성 등이 주요원인으로 지목 되고 있다.

그러나 한국은 아직 입원병실의 기준병실이 5 인실 이상인 경우가 대부분이어서 병실의 과밀화에 수반된 많은 문제점들 이 제기되고 있다. 이에 따라 한국은 병실의 정원기준을 4 인 이하로 하자는 의견이 지속적으로 제기되고 있다. 일례로 최 근 건립추진 중인 1000 병상 규모의 마곡지구 이화여자대학의 과대학 부속병원은 병실이 모두 1인실로 계획되고 있다.

아직 국내 의료법에는 병실의 정원에 관한 명확한 규정이 제시되어 있지 않다. 따라서 민간병원의 병실 정원을 강제화 하기 어려우며, 아직 4 인 기준병실에 대한 타당성이 충분히 입증되었다고 보기 어렵다. 따라서 국가의 관리가 비교적 용 이한 공공병원을 중심으로 4 인실을 운영하여 점진적으로 이 러한 내용을 민간병원에까지 확대하는 것이 필요하다. 이러한 점을 감안하여 본 연구에서는 공공병원의 4 인실에 대한 경제 적 가능성을 검토하였다. 이를 위해 입원병실의 경제성에 관 해 연구된 기존의 내용과, 34 개 공공의료원의 연보분석을 토 대로 공공병원의 4 인병실 도입에 관한 경제적 타당성을 검토 하였다. 본 연구의 결과는 다음과 같다.

1) 공공병원은 $77 \%$ 가 경상수지 적자를 기록하고 있다 (2012년 기준). 병실입원료에 있어서 입원료원가가 보험수가 보다 더 높아 공공병원의 의료수지 적자폭을 더 키우고 있는 실정이다. 더욱이 지방의료원은 병상수가 더 많을수록 의료원 의 적자폭이 더 큰 것으로 나타나 공공병원의 병상수를 늘리 는 것이 병원의 경제성 향상에 도움을 준다고 보기 어렵다.

2) 5 인병실을 기준병실로 운영하고 있는 공공병원의 5 인 실을 4인실로 전환하는 경우 병상이용율이 상승하여 실제 입 원 환자수의 감소분이 크지 않을 수 있다. 평균적으로 한 병 원당 약 5 명 내외의 입원환자 감소가 예상되지만, 신포괄수 가제의 적용으로 입원환자의 평균재원일수가 줄어들게 되면 4인실 전환에 따른 입원환자의 감소가 더욱 미미할 것으로 예상된다.

3) 지방의료원의 기준병실이 4 인실로 구성된 비율과 의료 원의 의료수지와의 상관성은 거의 없는 것으로 나타났다. 즉, 
병동의 기준병실을 4 인실로 하는 것이 병원의 수익성 악화에 영향을 미친다고 보기 어렵다.

위의 세 가지 연구결과를 감안하면 공공병원에 있어 5-6인 용 기준병실을 4 인용 기준병실로 전환하여 전체 병원의 병상 수가 감소되더라도 병원의 수익성이 악화된다고 보기 어렵다 는 것을 알 수 있다. 또한 4인병실 도입에 따른 입원환자 만족 도의 향상, 원내 교차감염의 감소 등의 이점을 고려하면 공공 병원의 기준병실을 4 인실로 전환하는 것이 타당한 것으로 판 단된다. 특히 구미 의료선진국의 경우 다인실보다는 병실의 정원을 2 인 이하로 구성하고 있는 추세를 감안한다면 한국도 점진적으로 병실의 정원을 줄여나가야 할 것이다.

본 연구는 주로 병원에서 제시하고 있는 연보 및 수익성 지 표를 토대로 이를 건축적인 특성과 연관시켜 그 상관성을 분 석하였다. 그러나 통계분석에 사용한 34 개 공공의료원의 연 보가 최신의 자료가 아닌 점8), 병실료 수가개편에 따라 향후 4인병실의 경제성분석이 달라질 수 있다는 점, 그리고 4인병 실 등 병실의 정원 이외에도 병실의 경제성에 영향을 미치는 외부변수의 상존 가능성이 있다는 점 등은 본 연구의 한계가 되며 이를 감안한 연구결과의 해석이 필요하다.

결과적으로 본 연구는 공공병원의 기준병실을 4 인실로 하 더라도 거시적인 입장에서 병원의 수익성이 악화되지 않는다 는 것을 제시하였다는데 그 의의를 찾을 수 있다. 물론 개별 병원별로는 4 인실의 기준병실화가 각 병원의 경제성에 다양 한 영향을 미칠 수 있을 것으로 본다. 본 연구의 연구방법을 민간병원에도 적용한다면, 병원의 기준병실 정원이 병원의 입 지, 병원의 규모, 병원의 등급 및 성격 등에 따라 각 병원의 경영성과에 어떠한 영향을 미치는지를 통계적으로 분석할 수 있을 것이다.

\section{References}

권순정, 채철균, 최광석, 2013. 05, 지역거점 공공병원 병동부 건축계획 기준 개발, 보건복지부, 한국의료복지건축학회

보건복지부, 2011, 지방의료원(34개) 연보 2010

보건복지부, 2012.7, 2013년 지역거점공공병원 기능보강 국고지원사업 지침

보건복지부 공공의료과, 2010. 12, 지역거점병원 발전방안 실행계획(내 부자료)

보건복지부, 국립중앙의료원, 2011년 지방의료원 운영진단 및 개선방 안 연구, 2011

신영석; 신현웅; 유근춘; 신호성; 박실비아; 김진현; 김진호; 노윤호; 임지 원; 나종익; 김태은; 안은숙; 김성재, 2012, 유형별 상대가치 개선을 위한 의료기관 회계조사 연구, 한국보건사회연구원

연구공동체 건강과 대안, 2008. 12 , 의료서비스 질 향상을 위한 병원 인 력 구조 개선 방안 - 간호 인력을 중심으로,

한국보건산업진흥원, 2012. 12, 2012년 의료기관 회계기준 운영보고서
Chai, Choul Gyun; Choi, Kwongseok; Kwon, Soonjung, 2013, A Study on the Planning of the Four- bed room Unit in Public Hospitals, Journal of Korea Institute of Healthcare Architecture, v.19 n.3, 2013. 08

Facility Guidelines Institute, 2010, Guidelines for Design and Construction of Healthcare Facilities

The Kyunghyang Shinmun, 2014.07.08. http://news.khan.co.kr/ kh_news/khan_art_view.html?artid $=201407082119495 \&$ code $=$ 940601

Ministry of Health and Welfare, 2013, Ministry of Health and Welfare Statistical Year Book, 2013

Samil, 2012. 8, 2012 Public Hospital Evaluation Programme : Survey Report, Ministry of Health and Welfare

접수 : 2014년 6월 30일 1차 심사 완료 : 2014년 7월 18일 게재확정일자 : 2014년 8월 8일 3 인 익명 심사 필

8) 2010 년 연보를 활용하였음. 